\title{
Gamification and deep learning approaches in higher education
}

\author{
Lidia Aguiar-Castillo *, Alberto Clavijo-Rodriguez, Lidia Hernández-López, \\ Petra De Saa-Pérez, Rafael Pérez-Jiménez
}

IDeTIC, Universidad de Las Palmas de Gran Canaria, Juan de Quesada 30, Las Palmas de Gran Canaria, Spain

\section{A R T I C L E I N F O}

\section{Keywords:}

Gamification

Deep learning approach

Higher education

Student commitment

HEgameApp

\begin{abstract}
A B S T R A C T
Gamification is a tool that has been used to promote commitment and motivation to students. This fact, coupled with the intensive use made by students of their smart phones, has led to the development of the HEgameApp application. This study shows that students' satisfaction will be influenced directly by application features, and it will influence pro-deep-learning approaches. Besides, the initiative will be visible through word of mouth. According to this study a gamified application can contribute to the pro-deep-learning approaches as students wish to expose their private learning-related actions to friends. An interesting finding of this study is the connection between the users' satisfaction and the promotion of behaviors related to deep learning strategies, since the more satisfied the students are, the more their deep learning strategies will be promoted. Another relevant finding comes from the teaching institution, as this type of initiative is very well accepted by the students and will improve the image, providing a smart academic, studentfocused reputation to the implementing academia.
\end{abstract}

\section{Introduction}

The impact of information and communication technologies has produced a significant change in today's life. This change has been reflected in the educational field, which has introduced among its objectives the acquisition of competences that train students in the use of digital tools (Almerich et al., 2005; De Diezmas \& Graells, 2016). Likewise, these skills sought after by society are framed in the context of adapting education to the European Higher Education Area. In addition to this training, the European Union intends for students to change their position from a passive role to being more active and autonomous in their learning. (García \& Cuello, 2009; Salinas, 2004).

Moreover, almost all universities provide students with digital-based content for their studies. This fact, together with the extensive use of smart mobile devices, has led instructors to incorporate these devices as a learning tool that complements traditional methods to find new ways to motivate students. Engaging students in educational processes is a challenge faced by any faculty member in all areas of education. It is common to find students consulting their cell phones in the middle of class. The punitive strategies of banning devices do not seem to be effective; furthermore, the introduction of technology in all sectors of our lives makes it challenging to fight against its use. In this scenario, gamification is presented as an ideal tool that contributes to achieving educational and training objectives through the use of digital resources (Lai, Lin, Jong, \& Hsia, 2014).

Gamification is a strategic tool that uses the help provided by technology and has been widely used in recent years to increase students' motivation and commitment to the learning process. Gamification, understood as the use of game techniques in non-playful

\footnotetext{
* Corresponding author. Universidad de Las Palmas de G.C, postdoctoral fellow.

E-mail addresses: laguiar@idetic.eu, lidia.aguiar@ulpgc.es (L. Aguiar-Castillo).
} 
environments, is being used more and more intensely in the distance higher education; however, its use in face-to-face education is not as widespread. (Deterding, Dixon, Khaled, \& Nacke, 2011). This use is intended to lead to greater motivation and commitment to the course content. So far, this strategy has been presented as a tool that makes the learning process more attractive and fun and, therefore, more productive (Barber, 2018; Barber \& Smutzer, 2017). If gamification is also linked to deep learning, it is revealed to instructors as an instrument to be taken into account in higher education both face-to-face and online. According to authors such as Graesser, Chipman, and Leeming (2009), it would be interesting to test the connection between deep learning and the emotion caused by games (Graesser, Chipman, and Leeming, 2009). More recent authors such as Acaso (2019) declare that deeper learning occurs when emotion and curiosity are aroused in the learner (Gandara, 2019). For this reason, the objective of this study to clarify whether gamification tools promote behaviors oriented towards deep learning is of vital importance. In particular this study analyzes the characteristics of the gamified application that influence student satisfaction and the effect that student satisfaction has on their deep learning strategy (Fig. 1).

Thus, the study has two main objectives: first, to analyze the relationship between the use of a gamified application, HeGameApp, and learning strategies, and, second, to delve into digital methodologies based on games that promote continuous, motivating, and autonomous learning, as well as the acquisition of the different competences required in today's knowledge society. Based on the objectives of this research, this study designed a pilot test based on gamification strategies named as HEgameApp, with the participation of 141 students of the Organizational Behavior subject in the Tourism degree of the University of Las Palmas de Gran Canaria.

The work is structured as follows: the first section describes the application's materials and methods. Theories about learning and its relationship with gamification are studied in section 3, and hypotheses are developed in section 4, proposing connections between student satisfaction and deep learning approaches. Section 5 is dedicated to explaining the methodology followed in this study, while section 6 analyzes the results. Finally, the results are discussed, and some conclusions are drawn.

\section{Material and methods}

In this section, it has been explained how the design of the application was accomplished.

\subsection{HEgameApp}

HEgameApp is an application designed to be used by students in which a triple objective is attempted:

1. It is intended to make students aware of the proper use of mobile phones in face-to-face classes. In this way, distractions are avoided during face-to-face educational activity.

2. It is also an application used as a platform for sharing knowledge since some researchers have found that observational learning is achieved via online sharing and peer evaluation (Yeh, Yeh, and Chen; 2012).

3. This application provides student information to faculty members, considering that the more knowledge instructors have about students, the greater will be their ability to empower them and, consequently, the effectiveness of teaching and the student learning outcome will improve (Paolini, 2015).

So, it seeks to incorporate technology into class dynamics and involve students in the learning processes. The application follows a criterion centered on gamification to achieve the specified objectives. The proposed gamification depends on obtaining points that can be exchanged for prizes, besides improving the subject's mark. This application provides tourism students with additional learning resources to publish content related to their subject, which is then evaluated by their peers. This process, which ends in students obtaining a score, aims to motivate them, using leaderboards and badges' gamification strategies (Aguiar-Castillo et al., 2020).

Based on this research's objectives, this study designed and pilot test an application based on gamification named HEgameApp. The application was designed and created by a multidisciplinary team whose members are part of the lDeTIC, Institute for Technological

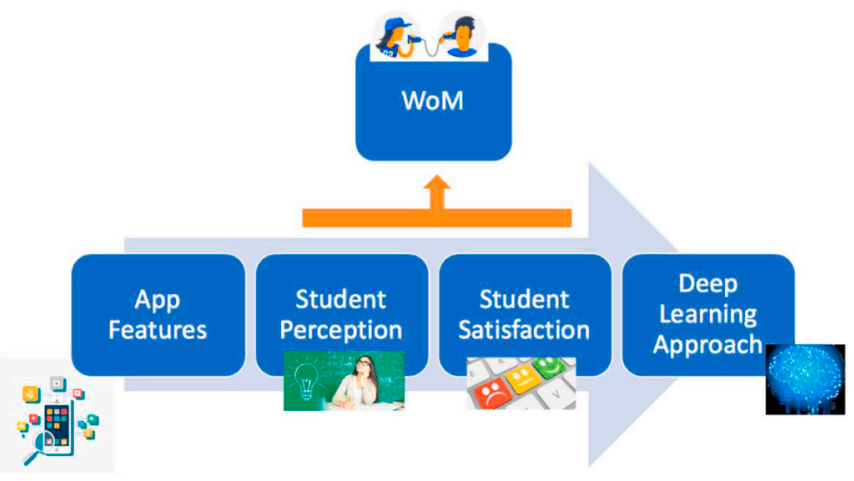

Fig. 1. Experimentation model. 
Development and Innovation in Communications, of the University of Las Palmas de Gran Canaria. It has been developed and implemented during the 2018-2019 academic year by the authors of this study. This team comprises both researchers from the social sciences, specifically those from the Hospitality and Tourism Management and Telecommunications studies, all of them renowned researchers in their area of knowledge and expertise in developing gamification applications. It was implemented during the 2018-2019 academic year.

In choosing the right technology for this application, the flexibility of implementation in the different devices is weighted as a fundamental requirement. The application has some characteristics. Firstly, it can be used in a range of devices, from mobiles to tablets to desktop computers. This tool can also be used in Smart phones independent of their operating system (Android, IOS) and storage capacity. There is a recent methodology that proposes a design of gamified applications focused on the varied preferences of users (Robson, Plangger, Kietzmann, McCarthy, \& Pitt, 2015).

In HEgameApp design, a generic approach was chosen because students to which the application is directed are diverse. Despite this approach, it has tended to focus on socializer students that focus on sharing their knowledge (Bartle, 1996). HEgameApp has several gamified tasks using game mechanics to afford an experiential value for students (Table 1).

\subsection{Design of the application}

The gamified application has been elaborated using the MDA (mechanics, dynamics, aesthetics) standard (Bartle, 1996; Hunicke, LeBlanc, \& Zubek, 2004). The application was stratified into layers. A mechanics layer, dealing with the algorithmic relationships and data structures; a dynamics layer concerning the student's utilization of mechanics and the interactions of the internal structures of the game itself; and a "sensations" layer that is directly associated with the final objective of the game: to provoke an emotional reply from the user. In this case, the target is directly related to three primary mechanisms: the implicit reward of knowing that contributes to share knowledge, obtaining points and, finally, the tangible reward received, a point in the final mark (see Fig. 2).

There is a choice of five different sections to contribute to Questions, Resources, Presentations, News, and Other. The content of each one has been specified so that users can organize their contributions in a structured way. Furthermore, the entry has been prompted through login and password identification.

The scores that appear on the leaderboards for each section are calculated according to the number of entries made by the user in

Table 1

Play tasks, game mechanics, motivational affordances and experiential values of HEgameApp website (Aguiar-Castillo, 2020: page 5).

\begin{tabular}{|c|c|c|}
\hline $\begin{array}{l}\text { 'Play' tasks: gamified website functions/tasks by } \\
\text { integrating them with game mechanics }\end{array}$ & $\begin{array}{l}\text { Game mechanic used for converting a desired } \\
\text { website function/task into a 'play' task }\end{array}$ & $\begin{array}{l}\text { Motivational affordances Experiential benefits/ } \\
\text { values }\end{array}$ \\
\hline $\begin{array}{l}\text { Upload a contribution (learning resources such as } \\
\text { theoretical contributions theory, web-based, } \\
\text { videos, articles, news, etc) }\end{array}$ & $\begin{array}{l}\text { Gain/add a 'point' to the user profile each time a } \\
\text { contribution is uploaded in order to achieve a higher } \\
\text { level of contributions and gain badges. } \\
\text { Badges = users get badges depending on the number } \\
\text { of contributions they upload. Badges have different } \\
\text { names (e.g. bronze, silver, gold) }\end{array}$ & $\begin{array}{l}\text { Competence (advancement and mechanics for } \\
\text { improving status), deep learning (study to } \\
\text { contribute) } \\
\text { User types: players, philanthropists }\end{array}$ \\
\hline Rate a contribution & $\begin{array}{l}\text { Gain/add a 'point' to the user profile each time a } \\
\text { contribution is rated in order to achieve a higher } \\
\text { level in leaderboards. }\end{array}$ & $\begin{array}{l}\text { Competence (advancement and mechanics for } \\
\text { improving status), autonomy, critical ability } \\
\text { (review other contributions), deep learning (study } \\
\text { other contributions) } \\
\text { User types: player, philanthropists }\end{array}$ \\
\hline $\begin{array}{l}\text { Upload a useful review - a learning resource-, } \\
\text { because other users can rate the quality of your } \\
\text { reviews; vote if the contribution is helpful; and } \\
\text { give a compliment }\end{array}$ & $\begin{array}{l}\text { Users gain points and these are added to their profile } \\
\text { information to demonstrate personal achievement } \\
\text { and to foster users' competition. } \\
\text { The points that students can get are from rating } \\
\text { contributions (community rating). }\end{array}$ & $\begin{array}{l}\text { Competence (advancement and mechanics for } \\
\text { improving status), deep learning (study to } \\
\text { contribute), socializing (to show a positive image } \\
\text { to their classmates) } \\
\text { User types: player, philanthropists, socializer }\end{array}$ \\
\hline $\begin{array}{l}\text { Add content and interact with others online in order } \\
\text { to allow users to enrich their learning } \\
\text { experience and knowledge sharing. By doing } \\
\text { so, users can continuously enhance and } \\
\text { "complete" their contributions }\end{array}$ & $\begin{array}{l}\text { Leaderboard - Scorecard, Status: "activity counters" } \\
\text { are used for showing to users their progress in } \\
\text { 'completing' their 'student profile' as well as their } \\
\text { online 'play' task performance concerning the } \\
\text { profile and the performance of other users. } \\
\text { Feedback about the 'play' task performance and the } \\
\text { progression in completing the student profile } \\
\text { influences the status of a user and increases the } \\
\text { chances that others perceived a user as a high-level } \\
\text { student; and is approached by others to give them } \\
\text { learning advice. } \\
\text { The 'User profile' (which is a type of a scorecard) } \\
\text { visualizes and provides information about the } \\
\text { following 'play' tasks: } \\
\text { - Type of badges achieved and points } \\
\text { - Number of contributions (total and per } \\
\text { category i.e. theoretical, web-based, videos, } \\
\text { articles, news) }\end{array}$ & $\begin{array}{l}\text { Competence (advancement and mechanics for } \\
\text { improving status), deep learning (study to } \\
\text { contribute), socializing (to show a positive image } \\
\text { to their classmates) } \\
\text { User types: player, philanthropists, socializer }\end{array}$ \\
\hline
\end{tabular}




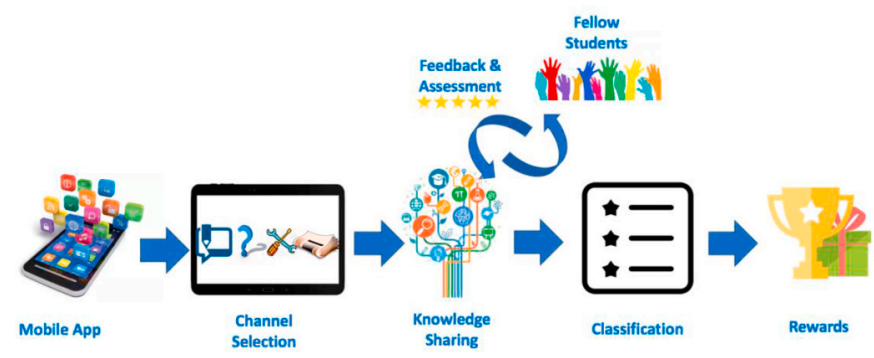

Fig. 2. The HEgameApp process of redeemed points by prizes.

that section as well as the number of evaluations they have made of the contribution of their peers. Besides, a factor is incorporated concerning the quality of the inputs and the assessments received from peers and the quality of their contributions. In this manner, the number and quality contributions are considered.

The formula to calculate this score, based on faculty expertise, is as follows:

Score $=(($ contribution $\times 0.3)+($ evaluations made $\times 0.2)+($ evaluations received $\times 0.1))$

The contributions evaluation system is based on five stars, or rather, each entry is given a score of from 1 to 5 points. Each time a contribution is evaluated, the score increases accordingly. The following is the formula for the evaluation of entries.

Evaluation of contribution:

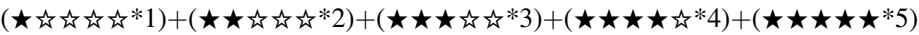

As the students achieve the established goals, they receive a badge of acknowledgment. The badges are bronze, silver, and gold and awarded according to the level reached, and when a student has a gold badge for each section, they also receive a diamond badge.

A more detail description, the application had not only a computer interface but also a relational database.

\section{Literature review}

\subsection{Student learning process}

The previous literature has shown that the learning process -and, together with it, the student's academic performance-is influenced by both cognitive factors and affective-motivational factors (Pintrich \& De Groot, 1990; Tous \& Amorós, 2007). In this sense, the motivation of the student is considered an essential element of the training activity. This importance is due to the significant influence that motivation has on learning, both in the process itself and in the results. It is not easy to address the problem of motivation in the academic field because there are many factors, guidelines, and models that deal with it from very different perspectives. This study is based on the dual approach offered by the distinction between intrinsic and extrinsic motivation (Ryan \& Deci, 2000). The intrinsic motivation has its origin into people and makes individuals act due to the activity itself like them, it is interesting, people enjoy it, and it does not constitute a means to achieve other goals, but is the end pursued. On the other hand, extrinsic motivation is that which comes from outside and leads individuals to an action that will reward them or allow them to reach other goals, that is, acting will be the means or instrument to reach his end (Deci \& Ryan, 1985; Eccles \& Wigfield, 2002).

Given this duality that encloses the construct of motivation, different effects can be expected on the learning process and its results according to the type of motivational orientation of the student (Tapia, 1998). According to EYSENCK (1985), intrinsic motivation increases the personal feeling of competency and self-determination. For Lepper (1988), the student with an intrinsic motivational orientation is willing to make a more considerable effort in the realization of learning tasks, is involved in processing more complex and enriching materials, while using learning strategies more profound and effectual. Also, Reeve (2002) concludes that intrinsically motivated students have greater academic success than extrinsically motivated ones. Some researchers have shown that learning strategies are better described from two factors called deep and surface learning (Baeten, Kyndt, Struyven, \& Dochy, 2010). Surface learning is associated with limited interest in learning tasks or memorizing and reproducing elements that seem appropriate. Deep learning, on the other hand, is associated with attempts to understand a topic if it is of their sincere interest or if they can see its relevance for their educational projection (Kember, 1997).

In short, there seems to be a consensus that intrinsic motivation generates more significant benefits than the extrinsic one in the academic sphere since it generates more significant effort and commitment of the student concerning their learning. However, very often, students face disciplines that are not interesting or attractive but are essential for their training. In these cases, providing rewards or establishing systems of sanctions is the only strategy left in the hands of the faculty to motivate students towards behaviors that favor their learning process. In this sense, based in the game mechanics, beyond allowing faculty members to establish reward systems, provides an additional attraction to the discipline. Introducing the elements that characterize the game (gamification) can make learning activities become a source of fun and thus generate intrinsic motivation (Malone \& Lepper, 1987; McGonigal, 2011).

For Malone and Lepper (1987), making learning more exciting and fun means that the students generate a higher intrinsic 
motivation. Thus, replicating the traits that characterize the game in the learning activities allows us to create an environment of intrinsic motivation in a teaching context. The use of tools, such as HEgameApp, allows the design of gaming experiences that meet all these requirements and, therefore, facilitate the creation of intrinsically motivational environments.

Likewise, the application of the motivational, educational model ARCS (Attention, Relevance, Confidence, Satisfaction) by Keller (2009) is useful in this context of gamification. This model is supported by the idea that motivation in the educational field requires that learning make sense and be meaningful for the student. Hence, the educational activity must be based on the principles of attention, relevance, confidence, and satisfaction to achieve this motivation. The principle of attention refers to the need to awaken the student's interest and curiosity towards the learning object or activity. The relevance implies that the student appreciates the importance that can have for him to learn the matter, problem, or concept that is being taught. Trust is achieved by creating expectations of success, that is, that students understand what is being demanded, and they believe to be capable of achieving it. Finally, learning must provide satisfaction through the sense of achievement, of a reward or of satisfying a need.

Based on this theoretical framework, HEgameApp can favor the behavior and learning outcomes of students (Wang \& Lieberoth, 2016). In this sense, previous research indicates, on the one hand, that this type of initiatives favors the participation of students in class and fosters an entertaining and fun learning environment (Fernández-Mesa, Olmos-Peñuela, \& Alegre, 2016; Rodriguez-Fernandez, 2017); and, on the other hand, that these learning platforms based on games are an effective way of learning for students (Laski \& Siegler, 2014; Plass et al., 2013).

\subsection{Gamification and learning}

The learning process has undergone many changes in recent years, which have been driven mainly by the evolution of ICT (Almerich et al., 2005; Navarro, 2017). These changes have modified the roles traditionally played by instructors and students - where students have a more engaged role in their learning process - and teaching methodologies, in which the implementation of ICT has become an instrument key to the acquisition of different knowledge and competences (García \& Cuello, 2009; Salinas, 2004).

In this new culture of university training, students are more autonomous and responsible for their learning process, so it is necessary to encourage activities that increase student involvement (Delgado \& Cuello, 2006; García-Beltrán, Martínez, Jaén, \& Tapia, 2016).

The use of play tools in non-playful environments, in this case, the educational one, is one of the most accepted definitions of gamification (Deterding et al., 2011). The psychological support of the use of these elements is motivation that can be conceptualized in two distinct characteristics: intrinsic, where a behavior or action is performed because it is associated with an internal value; and extrinsic where external rewards such as money or status are granted in exchange for a continued engagement to a particular behavior (Zichermann \& Cunningham, 2011). The point is trying to create extrinsic drivers that are internalized and become intrinsic pseudo-drivers, that is, incorporate the extrinsic drivers. Indeed, in the design of an application, it is a prerequisite to use motivational tools, both intrinsic and extrinsic, so that the likelihood of obtaining the desired behavior increases. Also, the intrinsic driver should be generalized as much as achievable, because due to the noteworthy variability of human beings, it is necessary to involve the most considerable number of people who are influenced by these drivers. This fact is so required since it has been shown that intrinsic motivators produce greater satisfaction in the user-player (Ryan \& Deci, 2000). There are a series of game procedures that have to be configured and are necessary to provoke the student's motivation. Feedback and positive reinforcement are demanded through the identification of accomplishment, improving status with colleagues, friends, and family (Zichermann \& Cunningham, 2011). The gamified practices, although they are not games, are created to leverage human psychology in like manner that games do. It shows that gamification is a more rewarding option, and therefore effective than conventional techniques of motivation and loyalty because, in the game, motivation is implicit (Werbach \& Hunter, 2012).

In this sense, gamification through ICTs takes on particular importance, the aim of which is to transfer the dynamics of games to external contexts, such as, for example, the educational sphere. Students are the leading players in the game and, from this protagonist role, they must make decisions, take on challenges, compete, and maximize their rewards (Koster, 2013). Through gamification, learning is more fun, entertaining, and attractive; hence, an improvement of learning processes and greater effectiveness in the process of acquiring knowledge and skills are getting. Likewise, the use of games favors the student's active participation in the classes, increasing their motivation and helping them to overcome the fear of making mistakes that may lead them not to participate (Zarzycka-Piskorz, 2016).

For a gamified application to augment its likelihood of obtaining an improvement in behavior, it is essential to establish that there is a normative influence among the students of a digital community. In other words, a student can begin to contribute with knowledge to adapt to the pro-learning behavior of the rest of the students in a way that produces a feeling of acceptance (Hamari \& Koivisto, 2015).

Other evidence indicates that the use of methodologies based on digital games improves the satisfaction level of the students and their academic results (Fernández-Mesa et al., 2016; Plass et al., 2013; Rodriguez-Fernandez, 2017). The elements of the game create opportunities for the social diffusion of ideas and behaviors, which makes visible to friends and colleagues actions that are intrinsically private (Aguiar-Castillo, Clavijo-Rodriguez, De Saa-Perez, \& Perez-Jimenez, 2019). Another advantage that gamified applications can supply to the learners is detailed information on how to develop their pro-learning behavior. Often students have doubts on standards and schedules for their studies. It is possible that their learning approach is more effective if students receive specific and easy to understand instructions from their fellows, always supervised by the instructor (Nilson, 2003).

There is no lack of objection to these gamification tools used by areas as diverse as education, government, and marketing. Some critical experts suspect the ethic of using the game to change human behavior, the manipulation of behavior through game tools (Anderson \& Rainie, 2010). 


\section{Hypothesis development}

\subsection{Technology acceptance model (TAM) and student satisfaction}

Since the beginning of studies on the adoption of technology, it has been accepted that the user makes an analytical decisionmaking process based on the cost-benefit conjunction. Thus, it is used the Theory of Reasoned Action, TRA (TRA), to support that most of the relevant social behaviors are under the volitional control of the subject. Being the human being a rational being who systematically processes the information available, uses structured information to form the intention to carry out or not to carry out a behavior specific (Ajzen \& Fishbein, 1977). If the theory of the reasoned is adapted to technology, it results in the development of the technological Acceptance Model. TAM considers that the two main attributes necessary to accept an information system are: perceived ease of use and perceived utility (Davis, 1989; Yoo, Kwon, Na, \& Chang, 2017). One more factor to point out is the effect that perceived ease of use exerts on perceived usefulness, which indicates that the user considers the application less useful if they find it challenging to use (Calisir \& Calisir, 2004; Wirtz \& Bateson, 1999). It has also been found that the perception of enjoyment is an essential value that players take into account in their game behavior, and that causes them to perceive the usefulness of the application to a greater extent. This perceived flow produces a higher perception of the usefulness of the gamified application (Li, 2014).

Based on the above arguments, the following hypotheses have been put forward:

H1. Perceived hedonic benefits about the gamified app will positively affect perceived usefulness about the gamified application.

H2. Perceived ease of use about the gamified app will positively affect perceived usefulness about the gamified application.

On the other hand, it has been detected that user satisfaction is directly related to the usability of the application, the ease of navigation, interactivity, and responsiveness (Palmer, 2002). Previous works indicate that the perceived usefulness of the application has a direct effect on user satisfaction (Aguiar-Castillo, Clavijo-Rodriguez, Saa-Perez, \& Perez-Jimenez, 2019; Mahmood, Burn, Gemoets, \& Jacquez, 2000; Zviran, Pliskin, \& Levin, 2005). It is more likely that the end-users will be more satisfied if they believe that using the system will enhance their performance in the target of the application (Mawhinney \& Lederer, 1990; Vlahos \& Ferratt, 1995).

Another notable perspective developed in previous studies is the direct effect that perceived hedonic benefits, understood as perceived fun or enjoyment, exerts on user satisfaction, here, student satisfaction. Several studies have explored the effect of fun, pleasure and excitement factors on user satisfaction, finding that it is always important and significant (Hsu \& Chiu, 2004; Wirtz \& Bateson, 1999). In this way, it is noted that the perceived hedonic benefits are even more important than perceived usefulness (Kang \& Lee, 2010). Besides the impact of emotions as fun or pleasure affect user satisfaction, not only directly, but also through perceived usefulness (Saber Chtourou \& Souiden, 2010). Moreover, students can consider perceived hedonic benefits as a part of the perceived utility of the application (Scarpi, 2006).

Therefore, the following hypotheses are proposed:

H3. Perceived hedonic benefits about the gamified app will positively affect student satisfaction about the gamified application.

H4. Perceived usefulness about the gamified app will positively affect student satisfaction about the gamified application.

H5. Perceived ease of use about the gamified app will positively affect student satisfaction about the gamified application.

\subsection{Word of mouth (WoM)}

The perceived usefulness of an application implies to have a positive effect on the student's purpose to recommend it, that is, the word-of-mouth consequence should be met to the extent of the utility of what is provided is perceived. However, it must be explained that the literature states that for this relationship to work, the usefulness of the application must be combined with its originality. In this specific case, if the students perceive the application as useful during their studies, they will divulge his kindness among their acquaintances. Besides, sometimes the level of utility is measured by the level of enjoyment of the application, the functional hedonic benefits. In the case of gamified application and taking into account that the hedonic benefits are an intrinsic part of the characteristics of the application, they will influence in the same way the intention to recommend it (Moldovan, Goldenberg, \& Chattopadhyay, 2011).

On the other hand, the reason to share a positive WoM may be due, for some to a desire to enhance themselves, and for others to a hope to gain social status. Likewise, ease of use, also called convenience value by some authors, seems to have a decisive influence on the intention to recommend a service, in this case of using the application. It is considered that this facility is appreciated by the userstudent as positive in their appreciation of the application, and therefore in their intention to tell their experience to their peers. (Pihlström \& Brush, 2008). That is, the pro-learning behavior derived from the student's satisfaction arouses a feeling of altruism that makes the person wants to recommend the application as a kind of exhibition in front of his friends and acquaintances (Kim, Kim, \& Kim, 2009).

In the context of this research, the following hypotheses were derived:

H6. Perceived hedonic benefits about the gamified app will positively affect gamified application WoM.

H7. Perceived usefulness about the gamified app will positively affect gamified application WoM.

H8. Ease of use about the gamified app will positively affect gamified application WoM.

The magnitude of satisfaction of the individual with the experience of the service is a precedent to recommend it (Bitner, 1990), this 
degree of satisfaction generates a positive effect from word of mouth (WoM) (Anderson, 1998). It has been found that those user-students who are pleased with an activity are more likely to declare favorable review. Moreover, the intentions of a student's behavior are an effect of the perceived values; therefore, if students are satisfied with an application, they will recommend it, even if they realize that this application has contributed to their pro-learning behavior they will also continue in their intention to WoM it (Zeithaml, Berry, \& Parasuraman, 1996; Yu, Zo, Kee, \& Ciganek, 2013).

So, this study hypothesises that:

H9. Student satisfaction about the gamified app will positively affect gamified application WoM.

\subsection{User satisfaction and deep learning approach}

The game tools used by the gamified applications provoke in the user a state of flow that, intrinsically, motivates the student to repeat pro-learning behaviors, that is, a habit is created as a result of the gamification. This state of flow may be consistent with the user's satisfaction. Some authors consider that flow is closely related to user satisfaction and the acceptance of information technology (Ghani \& Deshpande, 1994). Additionally, it is possible to find works in the field of health that have shown that new behavior becomes a habit through reiteration. They suggest that the frequency of this new behavior is significant so that it ends up engaging people to the practice (Phillips \& Gardner, 2016). What is more important, the development of this habit leads people to maintain the behavior permanently, even without the need to use gamification as an element of motivation. The change in long-term behavior will only appear if people execute pro-deep learning behavior many times and end up internalizing it (Judah, Gardner, \& Aunger, 2013).

Deep learning is associated with an intrinsic orientation in motivation (Deci and Ryan, 2002), motivation to study (Baeten et al., 2010). Thus, game mechanics that generate positive and intrinsically motivating experiences take advantage of intrinsic motivation, so naturally, students with a deep focus will be more engaged.

The support of good behavior is one of the effects of gamification, a result that seems to be more effective than punishments (Flora, 2012). As a consequence of this, an aftereffect emerges, the gamification enhances the satisfaction of the students when they are regularly informed about their progress, continuous feedback is submitted on the objectives that they are accomplishing. This fact favors a feeling of high individual performance that strengthens the behavior that the application supports (Park \& Kim, 2003).

The psychological effects, among which is the satisfaction with the gamified application, cause engagement to use it. Ajzen's (1981) Planned Behavior Theory (TBP) aims to predict conduct under the paradigm of perceived behavioral control. The subject evaluates the situation to carry out a behavior. If this evaluation originates from a state of satisfaction, it also provokes a greater interest in the study and, therefore, in deep learning strategies. Ivancevich, Konopaske, and Matteson (2006) and Key (2002) explain how greater satisfaction and performance in the subject (self-efficacy) derive towards a greater interest in the study and, therefore, in deep learning strategies (Mayora-Pernía \& Morgado, 2015). Based on the theory of planned behavior, it is predictable that student satisfaction will have a positive influence on the deep learning approaches (Ajzen, 1991; Keller, 2009). Besides, following the interaction equivalency theorem that states the three types of formal interaction (student-student, student-instructor, and student-content) are conducive to both learning and satisfaction, it can be noted that this experimentation promotes these three interactions highly. In this way, satisfaction indicates that deep and meaningful formal learning is more likely to occur (Croxton, 2014).

Based on the above reasons, the following hypothesis has been put forward:

H10. Student satisfaction about the gamified app will positively affect deep learning approaches.

After studying all the previous hypotheses, the following proposed research model is, therefore proposed in Fig. 3.

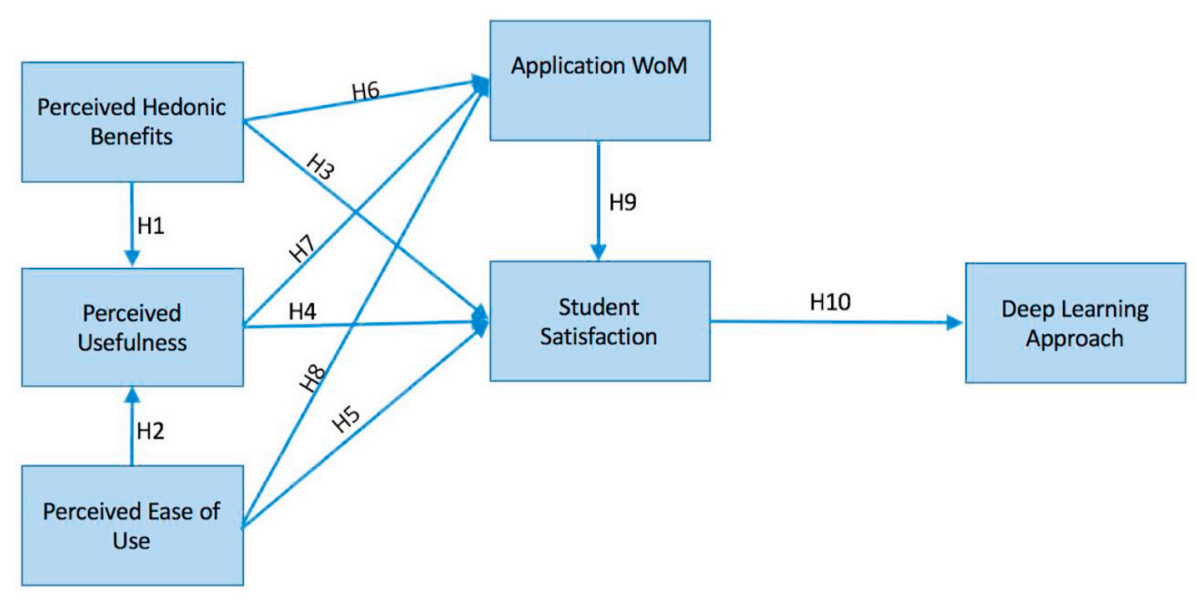

Fig. 3. Research model. 


\section{Research methods}

\subsection{Sampling procedure and sample}

As previously stated, survey data were collected from 141 students of the Organizational Behavior subject in the Faculty of Economics, Business, and Tourism at the University of Las Palmas de Gran Canaria. They were requested to answer a survey after testing the application. This university is located in the Canary Islands, Spain, whose economy is mainly based on Tourism. It is a young, public university (1989), with innovative studies within the Spanish higher educational panorama and a growing offer of online degrees such as the Hospitality and Tourism Management. ULPGC ranks second in Spain in international scientific productivity and is among the top 30 world universities in scientific productivity in Hospitality and Tourism Management. In the ranking of Shanghai, these studies occupy 23rd in the world, the first in Spain, and the fourth in Europe (Shangai Ranking, 2020). The sample has been selected in this university and the field of students of the degree of Hospitality and Tourism Management since it is tried to relate these learning strategies in an academic environment of higher education and Tourism studies. It is a sector especially relevant not only for this university but also for Canary society.

The survey was conducted throughout 2018-2019, using a convenience sampling where students were selected because of their accessibility and proximity to the researcher. (Saldaña, 2015). The survey was conducted on site-class, in the last session, since it was intended to know the students' impressions after using the gamified application HEgameApp. Researchers who developed the application, analyzed this study, and used it in their face-to-face classes led the survey. As listed in Table 2, 81 (57.4\%) of the respondents to the questionnaires were female, $57(40.4 \%)$ were male, and $3(2.1 \%)$ self-described as other. 127 (90.1\%) of the respondents were aged $\leq 24$, and 14 were aged $>24$. The most substantial proportion of respondents had a middle social status (88, $62.1 \%$ ). This social status was deduced from the survey's answer regarding the educational level and occupation of the students' heads of households. These analyzes were based on the ESOMAR matrix (Adimark, 2000).

\subsection{Measurement and analysis method}

All the variables were measured using scales adapted from previous studies. Items were estimated on a seven-point Likert scale in which 1 = strongly disagree, and $7=$ strongly agree. The research model is composed of the following variables:

- Perceived Hedonic Benefits (PHB) was measured with four questions adapted from (Davis, 1989; Van der Heijden, 2004), using the following items:

o "I think the experience of using the application is funny."

o "I think the experience of using the application is interesting."

o "I think the experience of using the application is exciting."

o "I think the experience of using the application is nice."

- Perceived Ease of Use (PEU) is estimated with four questions adapted from [Davis, 1989; Kim \& Chang, 2007), using the following items:

o "I think the navigation menu is intuitive enough."

o "I have not problems selecting section where I should enter the message."

o "I find it easy to use the application."

o "I think the messages from the application are easy to understand."

- Perceived Usefulness (PU) was measured from four items adapted from [Davis, 1989; Kim \& Chang, 2007):

o "I think the application is useful to study the subject."

o "I think it is interesting about the information which it gives me."

o "I think the information about the subject is useful to know it deeply."

o "I find the application useful to improve my mark."

- User Satisfaction (US), is estimated with four items adapted from [Kim \& Chang, 2007; Spreng \& Olshavsky, 1993): o "I think it is worth using this application."

Table 2

Demographic information for the sample.

\begin{tabular}{llll}
\hline Characteristics & & Frequency & $\%$ \\
\hline Gender & Male & 57 & 40.5 \\
& Female & 81 & 57.4 \\
Age & Other & 3 & 2.1 \\
& $\leq 24$ & 127 & 90.1 \\
Social Status & $>24$ & 14 & 9.9 \\
& Lower-middle & 3 & 2.1 \\
& Middle & 31 & 22.0 \\
& Upper-middle & 54 & 38.3 \\
& Upper & 53 & 37.6 \\
& & 141 & 100 \\
\hline
\end{tabular}


o "I think the application covers my expectations over the applications."

o "I like using the application again."

o "I would use the application more frequently."

- Application WoM (WoM) was estimated with three questions adapted from (Goyette, Ricard, Bergeron, \& Marticotte, 2010): o "I would recommend HEgameApp to my colleagues from other subjects."

o "I would recommend HEgameApp to my friends from other grades."

o "I would recommend HEgameApp to my instructors."

- Deep Learning Approach (DLA) was estimated from five questions based on (Biggs, Kember, \& Leung, 2001; Tsay, Kofinas, \& Luo, 2018):

o "I feel that virtually any topic can be highly interesting once I get into it."

o "I find most new topics interesting and often spend extra time trying to obtain more information about them."

o "I test myself on important topics until I understand them completely."

o "I work hard at my studies because I find the material interesting."

o "I spend a lot of my free time finding out more about interesting topics which have been discussed in different classes."

\section{Results}

\subsection{Measurement model}

All data were assessed applying path equation modeling in Amos software. Path Analysis is a multivariate method that allows to verify the adjustment of causal models as well as to identify the direct and indirect contribution that they make a set of independent variables to interpret the variability of dependent variables (Pérez, Medrano, \& Rosas, 2013). Construct validity and the reliability of the measurement model were evaluated based on confirmatory factor analysis. All values of composite reliability and Cronbach's $\alpha$ were all above 0.7 or higher. The indicator reliability was assessed based on the criterion that loading should be about 0.7 and that every loading below 0.4 should be omitted (Churchill, 1979). All loadings were higher than 0.7 and statistically significant at 0.01 , confirming excellent indicator reliability for the implement (see Table 3). The validity test was analyzed using the average variance extracted (AVE), and all constructs were greater than 0.5 (Fornell \& Larcker, 1981). Every construct of the square root of AVE was higher than the correlation between other variables (Fornell \& Larcker, 1981). Discriminant validity was verified (See Table 4).

\subsection{Hypothesis testing}

The evaluation of the adjustment aims to determine whether the relationships between the variables of the estimated model adequately reflect the correlations observed in the data. There are three types of adjustment goodness statistics: those of absolute adjustment (square chi), others of relative adjustment that compare the adjustment concerning another model (CFI) and those using

Table 3

Descriptive analysis.

\begin{tabular}{|c|c|c|c|c|}
\hline Items & Cross Loading & C.R. & AVE & Cronbach's $\alpha$ \\
\hline PEU1 & 0.820 & 0.920 & 0.742 & 0.882 \\
\hline PEU2 & 0.814 & & & \\
\hline PEU3 & 0.923 & & & \\
\hline PEU4 & 0.883 & & & \\
\hline PU1 & 0.878 & 0.934 & 0.779 & 0.904 \\
\hline PU2 & 0.891 & & & \\
\hline PU3 & 0.924 & & & \\
\hline PU4 & 0.835 & & & \\
\hline PHB1 & 0.944 & 0.965 & 0.872 & 0.951 \\
\hline PHB2 & 0.926 & & & \\
\hline PHB3 & 0.928 & & & \\
\hline PHB4 & 0.937 & & & \\
\hline US1 & 0.827 & 0.950 & 0.827 & 0.930 \\
\hline US2 & 0.943 & & & \\
\hline US3 & 0.941 & & & \\
\hline US4 & 0.922 & & & \\
\hline WoM1 & 0.934 & 0.941 & 0.841 & 0.902 \\
\hline WoM2 & 0.939 & & & \\
\hline WoM3 & 0.877 & & & \\
\hline DLA1 & 0.764 & 0.819 & 0.530 & 0.842 \\
\hline DLA2 & 0.824 & & & \\
\hline DLA3 & 0.783 & & & \\
\hline DLA4 & 0.782 & & & \\
\hline DLA5 & 0.760 & & & \\
\hline
\end{tabular}

PEU = perceived ease of use, $\mathrm{PU}=$ perceived usefulness, $\mathrm{PHB}=$ perceived hedonic benefits, $\mathrm{US}=$ user satisfaction, WoM = word of mouth, DLA = deep learning approach. 
Table 4

Test of discriminant validity.

\begin{tabular}{llllll}
\hline & 1 & 2 & 3 & 4 & 5 \\
\hline PEU & $\mathbf{0 . 8 6 1}$ & & & & \\
PU & 0.443 & $\mathbf{0 . 8 8 3}$ & & & \\
PHB & 0.472 & 0.755 & $\mathbf{0 . 9 3 4}$ & $\mathbf{0 . 9 0 9}$ & 0.917 \\
US & 0.571 & 0.767 & 0.801 & 0.873 & 0.911 \\
WoM & 0.515 & 0.701 & 0.437 & 0.445 & $\mathbf{0 . 7 2 8}$ \\
ADL & 0.232 & 0.455 & & \\
\hline
\end{tabular}

* Diagonal elements (bold) show the square root of the average variance extracted (AVE).

parsimonious adjustment that evaluate the fitting concerning the number of used parameters (NFI). None of these parameters provide all the necessary information to evaluate the model, so, usually, some of them are used concurrently (Pérez et al., 2013). The variance-covariance matrix was used to analyze the research model. Before verifying the hypotheses, it was corroborated the fit of the path model. As shown in Table 5 all the fitness indices signaled good model fits $\left(\mathrm{x}^{2} / \mathrm{df}=1.514, \mathrm{NFI}=0.989, \mathrm{TLI}=0.986, \mathrm{CFI}=0.996\right.$, RMSEA $=0.061$ ).

The results of the analysis are shown in Table 5. Perceived hedonic benefits (PHB) $(\beta=0.703, p<0.001)$ had statistically significant effects on the user satisfaction (US). Therefore, Hypothesis 1 was supported. Also, perceived ease of use (PEU) ( $\beta=0.111$, $\mathrm{p}<$ 0.1 ) has statistically significant effects on application WoM (WoM); consequently, Hypothesis 2 was supported. Besides, perceived hedonic benefits (PHB) influenced used satisfaction (US) significantly ( $\beta=0.465, \mathrm{p}<0.001$ ), so Hypothesis 3 was supported. The relation between perceived usefulness (PU) and user satisfaction (US) was statistically significant $(\beta=0.357, \mathrm{p}<0.001)$. As a result, Hypothesis 4 was supported. Regarding perceived ease of use (PEU), this factor had statistically significant effects on user satisfaction (US) $(\beta=0.152, \mathrm{p}<0.05)$. Consequently, Hypothesis 5 was supported. Moreover, perceived hedonic benefits (PHB) influenced on application WoM (WoM) $(\beta=0.180, \mathrm{p}<0.5)$. Thus, Hypothesis 6 was supported. However, neither the perceived usefulness (PU) nor the perceived ease of use (PEU) had effect on the intention to recommend the application (WoM). Accordingly, Hypothesis 7 and Hypothesis 8 were not supported. Finally, the influence of user satisfaction (US) was significant on application WoM (WoM) ( $\beta=$ 0.643, $\mathrm{p}<0.001$ ), and on deep learning approach (DLA) $(\beta=0.451, \mathrm{p}<0.001)$, thus the Hypothesis 9 , and Hypothesis 10 , were supported (Table 6, Fig. 4).

\section{Discussions and conclusion}

The number of innovative practices such as gamification in higher education has been growing day by day in recent years. It has been proven that gamification has led to an improvement in both attitude and commitment of students when faculty decides using it in their lectures (Subhash \& Cudney, 2018; Çakıroğlu, 2017). With these premises, this work is aimed to test if a positive influence of gamification on deep learning approaches can be found.

The developed application, HEgameApp, aims to take advantage of the persistent use of smartphones by students to incorporate it through the application to class dynamics among other objectives. Furthermore, digital competences are fostered while making students aware of the use of smartphones (Almerich et al., 2005; De Diezmas \& Graells, 2016). These circumstances are jointly used to promote deep learning approaches. It also provides an invaluable aid for faculty members as they know the progress of the student in real-time, and thus, can respond appropriately before problems worsen. The work presented here is the continuation of a previous one, where the most relevant factors for a successful app design were studied. In the current study, the technology acceptance model has been incorporated. It is demonstrated that the perceived hedonic benefits, the perceived usefulness, and the perceived ease of use influence the student's satisfaction (Keller, 2009; Kim \& Chang, 2007).

The perception of the utility of the application can be considered as influenced by the perceived hedonic benefits. However, this fact is not free of controversy. According to some authors, when the relationship between application and student ends, the commitment towards pro-deep-learning behavior may also disappear. It is necessary that the app characteristics that influence satisfaction, especially perceived hedonic benefits and perceived utility, allow the internalization of extrinsic motivations. Those exposing actions or benefits are perceived as useful to promote strategies of deep learning, as it can be offering tools that help in the learning of the subject in the channels of the application (Ryan \& Deci, 2000; Werbach \& Hunter, 2012).

On the other hand, the ease of use of the application will influence student's satisfaction, both directly and through usefulness, which is appreciated to a greater extent, as long as the application is simple to use. However, that ease of use is not enough to recommend the adoption of the application. It is possible for students who already have inherent skill in downloading and using online tools to be a feature that does not seem significant enough to recommend it. To the same extent, the usefulness of the application does not seem to be significant enough to recommend it either. When faculty members to complement scores propose HEgameApp in a class,

Table 5

Model fit for structural model test.

\begin{tabular}{|c|c|c|c|c|c|c|}
\hline Fit index & $X^{2}$ & $\mathrm{X}^{2} / \mathrm{df}$ & NFI & TLI & CFI & RMSEA \\
\hline Criterion & $\mathrm{p} \geq 0.05$ & $\leq 3$ & $\geq 0.9$ & $\geq 0.9$ & $\geq 0.9$ & $\leq 0.08$ \\
\hline Research model & $6.056(\mathrm{p}=0.195)$ & 1.51 & 0.989 & 0.986 & 0.996 & 0.061 \\
\hline
\end{tabular}


Table 6

Hypothesis test.

\begin{tabular}{|c|c|c|c|c|c|}
\hline & Path & Estimate & S.E. & Sig. & H Test \\
\hline $\mathrm{H} 1$ & Perceived hedonic benefits $\rightarrow$ Perceived usefulness & 0.703 & 0.062 & 0.000 & Supported \\
\hline $\mathrm{H} 2$ & Perceived ease of use $\rightarrow$ Perceived usefulness & 0.111 & 0.062 & 0.075 & Supported \\
\hline H3 & Perceived hedonic benefits $\rightarrow$ User Satisfaction & 0.465 & 0.069 & 0.000 & Supported \\
\hline $\mathrm{H} 4$ & Perceived usefulness $\rightarrow$ User Satisfaction & 0.357 & 0.068 & 0.000 & Supported \\
\hline H5 & Perceived ease of use $\rightarrow$ User Satisfaction & 0.152 & 0.050 & 0.003 & Supported \\
\hline H6 & Perceived hedonic benefits $\rightarrow$ Application WoM & 0.180 & 0.077 & 0.019 & Supported \\
\hline H7 & Perceived usefulness $\rightarrow$ Application WoM & 0.033 & 0.072 & 0.643 & No supported \\
\hline H8 & Perceived ease of use $\rightarrow$ Application WoM & 0.076 & 0.050 & 0.133 & No Supported \\
\hline H9 & User Satisfaction $\rightarrow$ Application WoM & 0.643 & 0.082 & 0.000 & Supported \\
\hline H10 & User Satisfaction $\rightarrow$ Deep Learning Approach & 0.451 & 0.075 & 0.000 & Supported \\
\hline
\end{tabular}

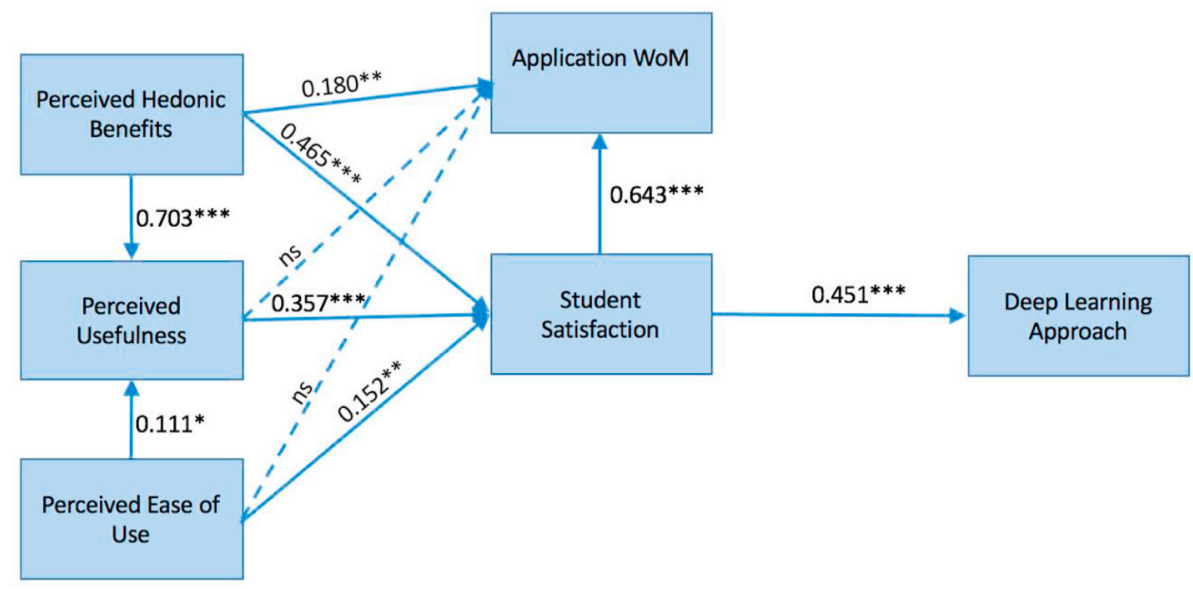

Fig. 4. Result model.

the usefulness is taken for granted, and it does not seem so relevant as to recommend its practice. However, the perceived hedonic benefits are distinguishing characteristics of the application and cannot be presumed; therefore, they influence the intention to recommend the gamified application by the students. This user satisfaction will have a positive impact on the fact of recommending the application. This phenomenon is probably due to two related reasons; first, students see the application as an aid to pro-deep learning approaches and, secondly, students wish to expose their actions, generally private, to acquaintances and friends, so that they will report a positive image to their social networks [Hamari \& Koivisto, 2015).

An interesting finding of this study is the connection between the satisfaction of the users and the promotion of behaviors related to deep learning strategies, since the more satisfied the students are, the more their deep learning strategies will be promoted. These actions can be taken as the satisfaction with the application comes from a combination of intrinsic and extrinsic motivations of the users. Thus, students are satisfied with the app because it helps them in their deep learning approaches, in addition, there is an altruistic feeling when sharing their findings with other peers (intrinsic motivation), but they also recommend the application to people in their environment to present themselves with a benevolent image (extrinsic motivation). The result is a beneficial habit not only for students who present that excellent image to their acquaintances, who benefit from the knowledge that would otherwise be more difficult to find. This commitment results in an improvement of the academic performance of the class as a whole, improving their learning strategies (Çakıroğlu, Ü., Başıbüyük, B., Güler, M., Atabay, M., \& Memiş, BY (2017).

Another relevant finding comes from the teaching institution, as this type of initiatives are very well accepted by the students and will produce an improvement in the image, providing a smart academic, student-focused reputation to the implementing academia. Finally, as it was already mentioned, according to our study, this type of initiative seems to be adequate to encourage deep learning approaches and sharing knowledge. It should be promoted from the institutions, which foster to improve their smart academic center image.

From the outcomes of this study, it is deduced the importance of developing gamified applications to improve student satisfaction and deep learning in face-to-face Hospitality and Tourism Management studies. This type of application increases the students' training in the subject and improves competences both inherent to the higher education framework required by the European Union and those others that will have an impact on their professional life. Competences such as critical capacity, autonomy, and the development of learning strategies are linked to the use of gamification, in addition to empathy among peers (Sigala, 2015). Another implication that can be deduced from this study is that gamification strategies can be used to improve the image of the educational center since the satisfied students are willing to spread their good reviews among friends and acquaintances. This factor is crucial for 
the centers since, with the introduction of online studies, the competition between centers will be fierce, and presenting an excellent image to the stakeholders involved in developing courses and collaborations with the university can make the difference among competing centers. Besides, previous studies have proposed the relationship between satisfaction and specific behaviors, such as environmental protection drifting into a habit (Aguiar-Castillo, 2020). Thus, deep-learning strategies can also be induced as a habit in students through these gamification strategies. Finally, these competences originated by habits (autonomy, critical ability, and empathy) are transferred to professional activity.

Closing, this work has also opened new research guidelines; it also has limitations due to the limited size of the test group and its components. It has been developed in a specific academic center and with a precise profile of the participants. Nevertheless, the study can be transferred to other types of curricula in other universities in different countries. Furthermore, the use of the questionnaire limits the information survey capacity, although its application in attitude studies can be considered adequate. This new research will be continued in the future in several aspects, such as the effect of promoting the different tools of gamification in the different levels of student motivation.

\section{References}

Adimark, S. (2000). El nivel socioeconómico ESOMAR. Manual de aplicación. Santiago, Chile: Autor.

Aguiar-Castillo, L. (2020). Contribución al estudio del impacto de la gamificación en el sector turístico: Promoción de comportamientos pro-ambientales. Tesis doctoral Universidad de Las Palmas de Gran Canaria.

Aguiar-Castillo, L., Clavijo-Rodriguez, A., Saa-Perez, D., \& Perez-Jimenez, R. (2019). Gamification as an approach to promote tourist recycling behavior. Sustainability, $11(8), 2201$.

Aguiar-Castillo, L., Hernández-López, L., De Saá-Pérez, P., \& Pérez-Jiménez, R. (2020). Gamification as a motivation strategy for higher education students in tourism face-to-face learning. Journal of Hospitality, Leisure, Sports and Tourism Education, 27, 100267.

Ajzen, I. (1991). The theory of planned behavior. Organizational Behavior and Human Decision Processes, 50(2), $179-211$.

Ajzen, I., \& Fishbein, M. (1977). Attitude-behavior relations: A theoretical analysis and review of empirical research. Psychological Bulletin, 84(5), 888.

Almerich, G., Suárez, J., Orellana, N., Belloch, C., Bo, R., \& Gastaldo, I. (2005). Diferencias en los conocimientos de los recursos tecnológicos en profesores a partir del género, edad y tipo de centro.

Anderson, E. W. (1998). Customer satisfaction and word of mouth. Journal of Service Research, 1(1), 5-17.

Anderson, J. Q., \& Rainie, H. (2010). Gamification: Experts expect'game layers' to expand in the future, with positive and negative results. Pew Internet \& American Life Project.

Baeten, M., Kyndt, E., Struyven, K., \& Dochy, F. (2010). Using student-centred learning environments to stimulate deep approaches to learning: Factors encouraging or discouraging their effectiveness. Educational Research Review, 5(3), 243-260.

Barber, C. S. (2018). Book review: 3D game lab. Rezzly Heroic Learning.

Barber, C., \& Smutzer, K. (2017). Leveling for success: Gamification in IS education.

Bartle, R. (1996). Hearts, clubs, diamonds, spades: Players who suit MUDs. Journal of MUD research, 1(1), 19.

Biggs, J., Kember, D., \& Leung, D. Y. (2001). The revised two-factor study process questionnaire: R-SPQ-2F. British Journal of Educational Psychology, 71(1), 133-149.

Bitner, M. J. (1990). Evaluating service encounters: The effects of physical surroundings and employee responses. Journal of Marketing, 54(2), 69-82.

Çakıroglu, Ü., Başıbüyük, B., Güler, M., Atabay, M., \& Memiş, B. Y. (2017). Gamifying an ICT course: Influences on engagement and academic performance. Computers in Human Behavior, 69, 98-107.

Calisir, F., \& Calisir, F. (2004). The relation of interface usability characteristics, perceived usefulness, and perceived ease of use to end-user satisfaction with enterprise resource planning (ERP) systems. Computers in Human Behavior, 20(4), 505-515.

Churchill, G. A., Jr. (1979). A paradigm for developing better measures of marketing constructs. Journal of Marketing Research, 16(1), 64-73.

Croxton, R. A. (2014). The role of interactivity in student satisfaction and persistence in online learning. Journal of Online Learning and Teaching, $10(2), 314$.

Davis, F. D. (1989). Perceived usefulness, perceived ease of use, and user acceptance of information technology. MIS Quarterly, 319-340.

De Diezmas, E. N. M., \& Graells, P. M. (2016). LA mejora del APRENDIZAJE A través de las nuevas tecnologías Y de la implantación del currículo bimodal. MULTIárea. Revista de didáctica, (7), 7-30.

Deci, E. L., \& Ryan, R. M. (1985). The general causality orientations scale: Self-determination in personality. Journal of Research in Personality, 19(2), 109-134.

Delgado, A. M., \& Cuello, R. O. (2006). La evaluación continua en un nuevo escenario docente. RUSC. Universities and Knowledge Society Journal, 3(1).

Deterding, S., Dixon, D., Khaled, R., \& Nacke, L. (2011, September). From game design elements to gamefulness: Defining gamification. In Proceedings of the 15th international academic MindTrek conference: Envisioning future media environments (pp. 9-15). ACM.

Eccles, J. S., \& Wigfield, A. (2002). Motivational beliefs, values, and goals. Annual Review of Psychology, 53(1), $109-132$.

EYSENCK, M. W. (1985). ATENCION Y ACTIVACION: CONGNICION Y REALIZACION. MICHAEL W. EYSENCK (No. HV6080. E97 1985.).

Fernández-Mesa, A., Olmos-Peñuela, J., \& Alegre, J. (2016). Valor pedagógico del repositorio común de conocimientos para cursos de dirección de empresas. @ tic. Revista D'innovació Educativa, (16), 39-47.

Flora, S. R. (2012). Power of reinforcement. The: SUNY Press.

Fornell, C., \& Larcker, D. F. (1981). Structural equation models with unobservable variables and measurement error: Algebra and statistics.

García-Beltrán, Á., Martínez, R., Jaén, J. A., \& Tapia, S. (2016). La autoevaluación como actividad docente en entornos virtuales de aprendizaje/enseñanza. Revista de Educación a Distancia, (50).

García, A. M. D., \& Cuello, R. O. (2009). Interacción entre la evaluación continua y la autoevaluación formativa: La potenciación del aprendizaje autónomo. REDU. Revista de Docencia Universitaria, 7(4), 1-16.

Ghani, J. A., \& Deshpande, S. P. (1994). Task characteristics and the experience of optimal flow in human-computer interaction. Journal of Psychology, 128(4), 381-391.

Goyette, I., Ricard, L., Bergeron, J., \& Marticotte, F. (2010). e-WOM Scale: word-of-mouth measurement scale for e-services context. Canadian Journal of Administrative Sciences - Revue Canadienne des Sciences de l Administration, 27(1), 5-23.

Hamari, J., \& Koivisto, J. (2015). "Working out for likes": An empirical study on social influence in exercise gamification. Computers in Human Behavior, 50, 333-347.

Hsu, M. H., \& Chiu, C. M. (2004). Predicting electronic service continuance with a decomposed theory of planned behaviour. Behaviour \& Information Technology, 23 (5), 359-373.

Hunicke, R., LeBlanc, M., \& Zubek, R. (2004). July). Mda: A formal approach to game design and game research. In Proceedings of the AAAI workshop on challenges in game AI (Vol. 4, p. 1722), 1.

Ivancevich, J. M., Konopaske, R., \& Matteson, M. T. (2006). Comportamiento organizacional. McGraw Hill.

Judah, G., Gardner, B., \& Aunger, R. (2013). Forming a flossing habit: An exploratory study of the psychological determinants of habit formation. British Journal of Health Psychology, 18(2), 338-353.

Kang, Y. S., \& Lee, H. (2010). Understanding the role of an IT artifact in online service continuance: An extended perspective of user satisfaction. Computers in Human Behavior, 26(3), 353-364.

Keller, J. M. (2009). Motivational design for learning and performance: The ARCS model approach. Springer Science \& Business Media. 
Kember, D. (1997). Evaluating the effectiveness of educational innovations: Using the study process questionnaire to show that meaningful learning occurs. Studies In Educational Evaluation, 23(2), 141-157.

Key, S. (2002). Perceived managerial discretion: An analysis of individual ethical intentions. Journal of Managerial Issues, 218-233.

Kim, D., \& Chang, H. (2007). Key functional characteristics in designing and operating health information websites for user satisfaction: An application of the extended technology acceptance model. International Journal of Medical Informatics, 76(11-12), 790-800.

Kim, T. T., Kim, W. G., \& Kim, H. B. (2009). The effects of perceived justice on recovery satisfaction, trust, word-of-mouth, and revisit intention in upscale hotels. Tourism Management, 30(1), 51-62.

Koster, R. (2013). Theory of fun for game design. O'Reilly Media, Inc.

Lai, C. H., Lin, Y. C., Jong, B. S., \& Hsia, Y. T. (2014). Adding social elements to game-based learning. International Journal of Emerging Technologies in Learning (iJET), 9 (3), 12-15.

Laski, E. V., \& Siegler, R. S. (2014). Learning from number board games: You learn what you encode. Developmental Psychology, $50(3), 853$.

Lepper, M. R. (1988). Motivational considerations in the study of instruction. Cognition and Instruction, 5(4), $289-309$.

Li, C. (2014). Evaluation of a theoretical model for gamification in workplace IS context. Doctoral dissertation, University of British Columbia.

Mahmood, M. A., Burn, J. M., Gemoets, L. A., \& Jacquez, C. (2000). Variables affecting information technology end-user satisfaction: A meta-analysis of the empirical literature. International Journal of Human-Computer Studies, 52(4), 751-771.

Malone, T. W., \& Lepper, M. R. (1987). Making learning fun: A taxonomy of intrinsic motivations for learning. In R. E. Snow, \& M. J. Farr (Eds.), Aptitude, Learning and Instruction. Cognitive and affective process analysis (pp. 223-253). Hillsdale: Lawrence Erlbaum.

Mawhinney, C. H., \& Lederer, A. L. (1990). A study of personal computer utilization by managers. Information \& Management, 18(5), $243-253$.

Mayora-Pernía, C. A., \& Morgado, N. F. D. (2015). Locus de control y rendimiento académico en educación universitaria: Una revisión bibliográfica. Revista Electrónica Educare, 19(3), 261-283.

McGonigal, J. (2011). Reality is broken: Why games make us better and how they can change the world. Penguin.

Moldovan, S., Goldenberg, J., \& Chattopadhyay, A. (2011). The different roles of product originality and usefulness in generating word-of-mouth. International Journal of Research in Marketing, 28(2), 109-119.

Navarro, G. M. (2017). Tecnologías y nuevas tendencias en educación: Aprender jugando. El caso de Kahoot. Opción, 33(83), 252-277.

Nilson, L. B. (2003). Improving student peer feedback. College Teaching, 51(1), 34-38.

Palmer, J. W. (2002). Web site usability, design, and performance metrics. Information Systems Research, 13(2), $151-167$.

Park, C. H., \& Kim, Y. G. (2003). Identifying key factors affecting consumer purchase behavior in an online shopping context. International Journal of Retail \& Distribution Management, 31(1), 16-29.

Pérez, E., Medrano, L. A., \& Rosas, J. S. (2013). El path analysis: Conceptos básicos y ejemplos de aplicación. Revista Argentina de Ciencias del Comportamiento (RACC), 5(1), 52-66.

Phillips, L. A., \& Gardner, B. (2016). Habitual exercise instigation (vs. execution) predicts healthy adults' exercise frequency. Health Psychology, 35(1), 69.

Pihlström, M., \& Brush, G. J. (2008). Comparing the perceived value of information and entertainment mobile services. Psychology and Marketing, 25(8), 732-755.

Pintrich, P. R., \& De Groot, E. V. (1990). Motivational and self-regulated learning components of classroom academic performance. Journal of Educational Psychology, $82(1), 33$.

Plass, J. L., O'Keefe, P. A., Homer, B. D., Case, J., Hayward, E. O., Stein, M., et al. (2013). The impact of individual, competitive, and collaborative mathematics game play on learning, performance, and motivation. Journal of Educational Psychology, 105(4), 1050.

Ranking, S. (2020). ShanghaiRanking's global ranking of academic subjects 2020 - hospitality \& tourism management. Retrieved from http://www.shanghairanking.com/ Shanghairanking-Subject-Rankings/hospitality-tourism-management.html.

Reeve, J. (2002). Self-determination theory applied to educational settings.

Robson, K., Plangger, K., Kietzmann, J. H., McCarthy, I., \& Pitt, L. (2015). Is it all a game? Understanding the principles of gamification. Business Horizons, 58(4), $411-420$.

Rodriguez-Fernandez, L. (2017). Smartphones and learning: Use of kahoot in the university classroom. Revista Mediterranea Comunicacion-Journal of Communication, 8 (1), 181-189.

Ryan, R. M., \& Deci, E. L. (2000). Intrinsic and extrinsic motivations: Classic definitions and new directions. Contemporary Educational Psychology, $25(1)$, 54-67.

Saber Chtourou, M., \& Souiden, N. (2010). Rethinking the TAM model: Time to consider fun. Journal of Consumer Marketing, 27(4), 336-344.

Saldaña, J. (2015). The coding manual for qualitative researchers. Sage.

Salinas, J. (2004). Innovación docente y uso de las TIC en la enseñanza universitaria. RUSC. Universities and Knowledge Society Journal, 1(1), 1-16.

Scarpi, D. (2006). Fashion stores between fun and usefulness. Journal of Fashion Marketing and Management: International Journal, $10(1)$, 7-24.

Spreng, R. A., \& Olshavsky, R. W. (1993). A desires congruency model of consumer satisfaction. Journal of the Academy of Marketing Science, 21(3), 169-177.

Subhash, S., \& Cudney, E. A. (2018). Gamified learning in higher education: A systematic review of the literature. Computers in Human Behavior, 87, $192-206$.

Tapia, J. A. (1998). Motivación y aprendizaje en el aula: Cómo enseñar a pensar. Santillana.

Tous, C. M., \& Amorós, M. M. (2007). Motivaciones para el estudio en universitarios. Anales de Psicología/Annals of Psychology, 23(1), 17-24.

Tsay, C. H. H., Kofinas, A., \& Luo, J. (2018). Enhancing student learning experience with technology-mediated gamification: An empirical study. Computers \& Education, 121, 1-17.

Van der Heijden, H. (2004). User acceptance of hedonic information systems. MIS Quarterly, 695-704.

Vlahos, G. E., \& Ferratt, T. W. (1995). Information technology use by managers in Greece to support decision making: Amount, perceived value, and satisfaction. Information \& Management, 29(6), 305-315.

Wang, A. I., \& Lieberoth, A. (2016, October). The effect of points and audio on concentration, engagement, enjoyment, learning, motivation, and classroom dynamics using Kahoot. In European conference on games based learning (Vol. 20)Academic Conferences International Limited.

Werbach, K., \& Hunter, D. (2012). For the win: How game thinking can revolutionize your business. Wharton Digital Press.

Wirtz, J., \& Bateson, J. E. (1999). Consumer satisfaction with services: Integrating the environment perspective in services marketing into the traditional disconfirmation paradigm. Journal of Business Research, 44(1), 55-66.

Yoo, C., Kwon, S., Na, H., \& Chang, B. (2017). Factors affecting the adoption of gamified smart tourism applications: An integrative approach. Sustainability, 9(12), 2162.

Yu, J., Zo, H., Kee Choi, M., \& Ciganek, A. P. (2013). User acceptance of location-based social networking services: An extended perspective of perceived value. Online Information Review, 37(5), 711-730.

Zarzycka-Piskorz, E. (2016). Kahoot it or not? Can games be motivating in learning grammar? Teaching English with Technology, 16(3), 17-36.

Zeithaml, V. A., Berry, L. L., \& Parasuraman, A. (1996). The behavioral consequences of service quality. Journal of Marketing, 60(2), 31-46.

Zichermann, G., \& Cunningham, C. (2011). Gamification by design: Implementing game mechanics in web and mobile apps. O'Reilly Media, Inc.

Zviran, M., Pliskin, N., \& Levin, R. (2005). Measuring user satisfaction and perceived usefulness in the ERP context. Journal of Computer Information Systems, 45(3), 43-52.

Lidia Aguiar Castillo is a postdoctoral fellow of the Institute for Technological Development and Innovation in Communications, University of Las Palmas de Gran Canaria, Spain. Her research interests include gamification, technology-enhanced learning and sustainability education. 
Lidia Hernández López is an associate professor of the Institute for Technological Development and Innovation in Communications, University of Las Palmas de Gran Canaria, Spain. Her research interests include gamification and technology-enhanced learning.

Petra De Saa Pérez is full professor of the Institute for Technological Development and Innovation in Communications, University of Las Palmas de Gran Canaria, Spain. Her research interests include human resource management, innovation, gamification, technology-enhanced learning, and sustainability education.

Rafael Pérez Jiménez is full professor of the Institute for Technological Development and Innovation in Communications, University of Las Palmas de Gran Canaria, Spain. Her research interests include Visible Light Communication, Optical Camera Communication, gamification, technology-enhanced learning, and sustainability education. 